\section{Predicting African trade considering uncertainty by scenario planning}

The growth of Africa's international trade

Ryuichi Shibasaki

Resilience Engineering Research Center, Graduate School of Engineering, The University of Tokyo, Tokyo, Japan

Masahiro Abe

Global Project Management Department, Pacific Consultants Co Ltd, Chiyoda-ku, Japan

Wataru Sato

General Affairs Department, Japan International Cooperation Agency, Kuala Lumpur, Malaysia

Naoki Otani

Ministry of Land Infrastructure Transport and Tourism Japan, Chiyoda-ku, Japan

Atsushi Nakagawa

Infrastructure and Peacebuilding Department,

Japan International Cooperation Agency, Kuala Lumpur, Malaysia, and

Hitoshi Onodera

Urban Development Department, Pacific Consultants Co Ltd, Chiyoda-ku, Japan

\begin{abstract}
Purpose - This study predicts the growth of Africa's international trade from 2011 to 2040 by accounting for the uncertainties in the continent.

Design/methodology/approach - This study applies a scenario planning method (SPM) to develop multiple future scenarios considering uncertainties inherent in African socio-economies related to the success or failure of economic and industrial policies (EIPs) and economic corridor development policies (ECDPs). Subsequently, based on these future scenarios, the growth of African international trade from 2011 to 2040 is predicted using the Global Trade Analysis Project (GTAP) model.

Findings - The predictions reveal that if the EIPs and the ECDPs are successfully implemented, Africa, as a whole, will experience a significant increase in trade, estimated at US\$1,905 billion and US\$1,599 billion for exports and imports, respectively, compared to the scenario in which they fail. However, the effects vary greatly by country or region and industrial sector. The results also show that African intra-regional trade is rapidly expanding and is the second-largest after trade with Europe followed by other continents.

Originality/value - SPM, which allows us to reflect the uncertainties affecting African international trade prediction, is applied to build the future scenarios. The study comprehensively predicts African future international trade by setting a wide range of exogenous variables and parameters (input conditions for the GTAP model) related to EIPs and ECDPs.
\end{abstract}

Keywords Scenario planning, GTAP, AfCFTA, African trade, Economic corridor development,

Trade forecast

Paper type Research paper

(C) Pacific Star Group Education Foundation. Licensed re-use rights only.

The authors would like to thank the members of the JICA Study Group "Project Study on the Grand Design for Global Logistics in the Indo-Pacific Region" for their helpful comments that greatly improved this analysis.
Received 29 July 2021 Revised 5 December 2021 Accepted 27 December 2021 
MABR

7,4

352

\section{Introduction}

African economies, wherein private consumption has for a long time played a major role, are at a turning point. In 2019, half of Africa's growth in gross domestic product (GDP) was attributable to investment, including foreign direct investment (the African Development Bank or AfDB, 2020). The African Continental Free Trade Area (AfCFTA) that was established in May 2019 to promote intra-African trade became operational in January 2021, although there are still issues, such as the fact that tariff exemptions or reductions have not yet been initiated as of June 2021. With these developments, Africa's international trade, including intra-regional trade in Africa, is expected to increase in the future. The International Monetary Fund (IMF, 2021) projected that exports and imports of goods and services in sub-Saharan Africa would increase by $70.8 \%$ and $54.7 \%$, respectively, by 2026 from 2011, the base year of this study. However, this increase in investment and international trade underscore the importance of improving the infrastructure gap in international trade. For example, the AfDB (2018) indicated that the existence of infrastructure gaps in the transport sector could hinder further economic development in Africa. Based on this background, at the seventh Tokyo International Conference on African Development (TICAD7) held in Yokohama in 2019, the Japanese government and African countries adopted the Yokohama Declaration to strengthen connectivity and promote regional integration, as well as efforts to realize sustainable development goals through infrastructure development in Africa (Ministry of Foreign Affairs of Japan, 2019). This implies that to accelerate Africa's economic growth, in addition to economic and industrial policies (EIPs) that encourage the expansion of trade and industrial development - such as the achievement of the AfCFTA and other free trade agreements (FTAs) and the advancement of technological innovation (TI) that supports economic and industrial activities - it is important to consider economic corridor development policies (ECDPs) that include infrastructure development endorsed by the advancement of various TIs, by forming well-connected transport networks.

Moreover, as Servén (1997) indicated, African socioeconomic uncertainties, such as the instability of political systems, government crises and volatility in terms of trade, hamper Africa's economic growth prospects. If these political and economic uncertainties were to improve, African economies would attract more foreign direct investments (AfDB, 2017). However, most studies have focused on analyzing uncertainties such as tariff rates, while fixing other parameters such as population, natural resource endowments and industrial development including the advancement of TIs. In other words, these studies did not consider the uncertainties that exist in Africa, such as changes in the population and labor supply, tariff rate changes caused by FTAs, TIs in industries and changes in the supply of natural resources. In the light of these shortcomings, various uncertainties in Africa need to be considered more broadly when examining future socioeconomic changes.

Therefore, this study predicts the value of Africa's future international trade based on multiple future scenarios regarding EIPs and ECDPs, while considering the wide-ranging uncertainties in Africa. This study first applies a scenario planning method (SPM) to construct three scenarios based on policies that consider future uncertainties in Africa, as inputs for the forecasting model. Subsequently, the Global Trade Analysis Project (GTAP) model, an applied general equilibrium model, is applied to make long-term forecasts by scenario on how Africa's international trade will be affected by the implementation of these policies.

The remainder of this paper is organized as follows. Section 2 reviews the relevant literature. An outline of the scenario-building process and its results are described in section 3. Section 4 presents an overview of the GTAP model and the settings of the various parameters based on multiple future scenarios. Section 5 presents the results of the future projections from 2011 to 2040 using the GTAP model and analyses Africa's future 
international trade, including intra-regional trade, for each scenario. Finally, section 6 presents the conclusions of the study and discusses future issues.

\section{Literature review}

The World Bank (2020) published a study to quantify the long-term economic impact of the AfCFTA based on its environmental impact and sustainability and applied a general equilibrium model that uses the GTAP database. They estimated that the AfCFTA would increase Africa's intra-regional trade by $81 \%$ by 2035 compared to 2020 and contribute to an increase in the real incomes of AfCFTA parties. The African Export-Import Bank (2018) also conducted a GTAP model analysis based on multiple policy scenarios for the AfCFTA. They found that setting appropriate tariffs can reduce the inefficiency of non-tariff barriers and increase the economic benefits of the AfCFTA. They also indicated that whereas some countries would enjoy the economic benefits of the AfCFTA, others would suffer economic losses due to changes in the terms of trade. Pasara and Dunga (2020) used the World Bank's model to delve into the different impacts of the AfCFTA by country and recommended the elimination of tariff and non-tariff barriers by the AfCFTA. Besides, some studies, including Chikhuri (2013), Anderson and Strutt $(2014,2016)$ provided long-term forecasts for African economies.

The results of the above studies are useful as they quantified the long-term impacts of policies and projects. However, in most of these studies, the parameters related to population and technological progress, other than the policies each study focused on in their analysis, did not vary between scenarios; thus, most of the existing studies did not fully consider a variety of uncertainties in Africa. For example, as the AfDB (2016) indicated, Africa's population is likely to fluctuate significantly in response to development trends, and accordingly, the logistics volume, which is generally considered to be partially correlated with population, is expected to fluctuate. This is in line with Dellink et al. (2020), who indicated that many studies adopted business as usual (BAU) scenarios by referring to other studies without sufficient consideration because of difficulties in terms of the reliability and costs of scenario building. To this end, Shibasaki and Watanabe (2012) undertook pioneering work to develop future scenarios by applying the Delphi method; they sent repeated questionnaires to many experts to consider more specific future trends in the international economy and uncertainties in international transport policies, including investment in logistics infrastructure and forecasted future trade volumes using the GTAP model based on future scenarios. However, as Kawai (2012) indicated, although the Delphi method has the advantage of using the collective knowledge of experts, there are weak causal relationships within scenarios, and the performance of long-term technology forecasting is not always good.

In this context, Zegras et al. (2004) examined the usefulness of SPM in long-term transport policies while considering uncertainty. SPM is a systematic way to develop specific plans and strategies in uncertain situations by crafting possible futures (O'Brien, 2000). Three types of future scenarios (i.e. predictive, normative and exploratory) envisioned in SPM, each of which focuses on the major factors that will affect the future, present multiple possible future scenarios in the form of a story about their causal relationships (Erdogan et al., 2009). Among them, the normative scenario, which is adopted in this study, can be applied when developing scenarios on the ideal future state envisioned (Chakraborty and McMillan, 2015). In recent years, SPM has been applied to long-term predictions of energy supply and demand and greenhouse gas emissions from a global perspective. For example, Japan's Institute of Energy Economics (2017) depicted a technological progress scenario for the world's energy supply and demand by 2050. Another example of the application of SPM is shared socioeconomic pathways (SSP) that were developed to analyze the long-term effects of socioeconomic factors, including GDP, population, land use, urbanization and technological progress on
The growth of Africa's international trade 
MABR

7,4

climate change (Brian et al., 2015). Ouedraogo (2017) applied SPM to Africa to examine multiple future scenarios for energy supply and demand, renewable energy deployment and greenhouse gas emissions in Africa.

In light of problems with existing studies on future projections for Africa and the importance of scenario development as indicated by Dellink et al. (2020), this study develops multiple normative scenarios to reflect the uncertainties that should be considered in future projections on Africa using SPM; based on these constructed future scenarios, future trends in international trade are forecasted, with a particular focus on Africa using the GTAP model.

\section{Building future scenarios}

This study applies SPM to develop a future normative scenario. According to Schwartz (1996), the following five steps are generally involved: [1] the main issues considered in the future scenario development are identified, [2] the drivers that determine the success or failure of the identified issues are identified, [3] the drivers are analyzed and ranked by critical indicators such as importance, controllability and uncertainty, [4] logics to develop future scenarios are set, and [5] scenarios are fleshed out based on the developed logics and by referring to the key drivers.

The main issue of this study is Africa's international trade, including intra-regional trade in the future, as summarized in Table 1. A study group consisting of several Japanese experts in transport planning and regional economic development was established for the scenario building; and 11 drivers that affect the main issue were extracted through brainstorming and follow-up discussions. Subsequently, seven drivers that would affect uncertainty in Africa's international trade in the future were extracted.

Among these drivers, progress in free trade has for many years been a source of uncertainty due to ongoing debates between the merits of free trade and protectionism. The Ministry of Economy, Trade and Industry of Japan (2020) mentioned that an increase in the size of the economy, a contribution to higher total factor productivity and lower disparities at a country level are among the benefits of free trade. However, as Morris (2014) indicated, the momentum toward free trade in African countries had not increased, although African countries had enjoyed the economic benefits of an increase in resource exports when resource prices soared; consequently, industrialization in Africa had lagged far behind other regions. A typical consequence is a lower share of intra-regional trade in Africa $(16.6 \%$ as of 2017; United Nations Conference on Trade and Development, 2019), compared with other regions of the world (68.1\% in Europe and $59.4 \%$ in Asia). In this regard, AfCFTA is a key international free trade policy to promote Africa's intra-regional trade in the future. However, the progress of the AfCFTA is still uncertain; for example, the Assembly of the African Union had put off the deadline for the conclusion of negotiations due to the COVID-19 pandemic (African Union, 2020). Therefore, this study considers that more time is necessary before the AfCFTA will be able to function practically, and thus a moderate trade bloc will first be formed in which multiple regional and other FTAs take effect to coexist on a long-term time scale with various stages of their realization.

Another important driver is the advancement and acceptance of TIs in major sectors in Africa. Various TIs are underway in various fields in Africa, including agriculture and food, natural resources and energy, and global logistics, owing to the rapid progress in information and communication technologies (ICTs). Further economic development may flow from such innovations, namely, a leapfrogging effect (Soete, 1985) where technologically backward countries can quickly catch up with advanced countries through the prompt adoption of the latest high technologies, without incurring significant costs to introduce these technologies. However, insufficient promotion and unacceptance of TIs due to a lack of highly qualified human resources and inadequate legal systems may cause economic stagnation in 
Future scenario building (brainstorming and discussion based on the SPM)

1st period: October 2017-March 2018 (5 sessions)

2nd period: January 2019-July 2019 (4 sessions)

Participating experts: 6 from universities, 7 from the private sector, 10 from the Japan

International cooperation agency (JICA)

Steps

Brainstorming and discussion results

1. Identify main issues of the scenario development

2. Identify drivers

Africa's international trade (including intra-regional trade) in the future

11 drivers affecting Africa's international trade were selected:

(1) population, (2) economic growth rate, (3) progress in free trade,

(4) TIs in major sectors, (5) agriculture and food, (6) natural resources

and energy, (7) global logistics, (8) realizing responsible supply chains,

(9) stimulation of consumer confidence, (10) climate change and

(11) war, conflict and terrorism

3. Analysis of drivers

4. Set scenario logics

5. Flesh out the scenarios based on the logic
7 drivers subject to uncertainties: (1) population, (2) economic growth rate, (3) progress in free trade, (4) TIs in major sectors, (5) agriculture and food, (6) natural resources and energy and (7) global logistics Three scenarios (BAU, successful scenario S1 and unsuccessful scenario S2) are prepared to consider the above uncertainties with the target year of 2040

BAU scenario: With partial cooperation in exploiting several regional economic communities and development agencies and other factors, Africa's international trade, including intra-regional trade, is expected to expand gradually with the gradual formation of moderate trade blocs, through the partial achievement of quality growth

Scenario S1: With full cooperation in exploiting various regional economic communities and development agencies and other factors, Africa's international trade is expected to expand significantly with the early formation of moderate trade blocs through the full achievement of quality growth

Scenario S2: Although modest trade blocs will be formed to some extent in Africa, industrial and trade structures for mutual trade will not be fully established, and development is expected to be overly dependent on imports from non-African countries
The growth of Africa's international trade

355

Table 1.

Summary of future scenario building

developing countries. In particular, this study assumes that uncertainties in the advancement of agricultural, energy and logistics TIs, as well as other developments in these sectors, could have a significant impact on Africa's future international trade, including intra-regional trade. For example, regarding agricultural TI, ICT-based smart agriculture will enable higher production levels in the future. Exporting surplus agricultural products driven by increased domestic production is a critical factor in increasing future international trade in Africa. However, the spread of agricultural TI may be hindered by political instability and weak governance, which can lead to the stagnation of growth in the agriculture and food sector.

Meanwhile, with the spread of ICT-related technologies, the transport environment is expected to improve through logistics TIs such as the automation of logistics vehicles and cargo handling operations, more sophisticated logistics management systems, last-mile transport using unmanned aerial vehicles and the computerization of trade procedures at borders. However, bilateral or multilateral cooperation that is necessary to fully enjoy the benefit of logistics TIs may be curtailed by protectionist trade policies and the lack of logistics infrastructure investment. From this perspective, the cooperation of African governments and regional economic communities and the support of development agencies will play an important role in the realization of ECDPs endorsed by these logistics TIs. Since 1970, many international organizations and developed countries have provided official development 
MABR

7,4

assistance to reduce poverty and address environmental problems in developing countries. For example, the Japan International Cooperation Agency (JICA) supports strategic regional development for sustainable and resilient economic growth through ECDPs, including the establishment of one-stop border posts for trade facilitation and investment in transport network infrastructure including roads, railways, inland waterways and seaports. If the transport environment in Africa is improved through ECDPs, synergistic effects with the AfCFTA are expected to expand Africa's international trade, including intra-regional trade.

Finally, as summarized in Table 1, three future scenarios (BAU scenario, successful scenario S1 and unsuccessful scenario S2) with the target year of 2040 were developed based on the above discussions on uncertainties in the drivers. In particular, these scenarios focus on the degree to which Africa's quality growth-incorporating inclusive, sustainable and resilient growth (Ministry of Foreign Affairs of Japan, 2020) - will be realized. The BAU scenario assumes the partial achievement of Africa's quality growth, whereas scenario S1 assumes the full achievement of Africa's quality growth, and scenario S2 assumes development dependent on imports from outside Africa.

Furthermore, these scenarios include descriptions of the expected international trade volume and its disparity among countries and industrial sectors, which could be used to validate the model's results.

\section{Trade forecasting model and parameter settings}

\subsection{Model overview and calculation conditions}

The GTAP model is a typical applied general equilibrium model. It assumes that households in each country consume both goods produced domestically and goods imported from each country, which are substitutable, to maximize utility. The producers are formulated based on cost-minimizing behavior in accordance with the Armington structure, which assumes substitution of imported goods, substitution between domestically produced goods and imported goods and substitution between intermediate goods. Each industry produces output goods by using multiple types of substitutable intermediate goods, which are a composite of domestically produced inputs and synthetic inputs imported from various countries, and factors of production, which are a composite of the factor inputs of skilled labor, unskilled labor, capital, natural resources and land. The basic GTAP model adopted in this study does not consider the movement of labor and capital across borders.

In this study, with reference to the method of Shibasaki and Watanabe (2012), we apply recursive dynamic (RD) calculations for six periods (2011-2016, 2017-2020, 2021-2025, 2026-2030, 2031-2035 and 2036-2040), by using the function "using updated database from last simulation" in the RunGTAP application software (Burfisher, 2011). Similar to other studies, which used the GTAP-RD model such as Kosuge et al. (2021) and Nugroho et al. (2021), the calculation results of the model for each period, such as capital accumulations, are used successively to obtain the results in the next period. Note that GDP in each county is given based on the scenarios, whereas total factor productivity in each country is instead endogenised in the model calculation in each period. By adopting this calculation method, considering various changes and uncertainties included in the scenarios set for each period, future predictions for the year 2040 are made.

The GTAP Data Base 9 (based on 2011 data; see Aguiar et al., 2016) and the GTAP-RD database (see McDougall et al., 2012) are used as the input condition for the model calculations. This study focuses on Africa, especially eastern and southern African countries that are the gateway to the Indo-Pacific region, the core of the world economy with about half of the world's population. Based on these criteria, the initial 140 countries/regions are aggregated into 31 countries/regions, as indicated in Figure 1. Regarding the industrial sectors, considering the cargo items and cargo types (such as containerized cargo and dry 


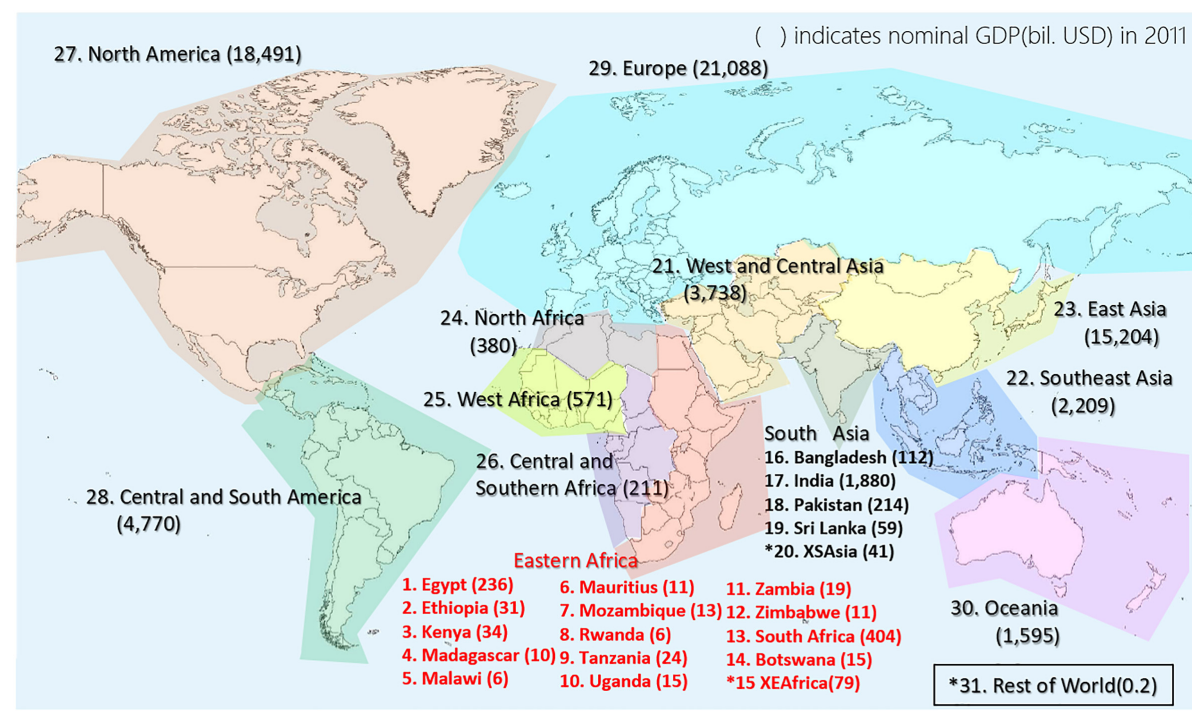

The growth of Africa's international trade

357

bulk cargo) focused on in this study, the initial classification of 57 industrial sectors is consolidated into 10 sectors: agriculture and food, coal, oil, gas, minerals, consumer products, industrial materials, motor vehicles, processing and assembling and services.

\subsection{Scenario settings for model calculation}

The three future scenarios developed in section 3 are qualitative representations; therefore, it is necessary to set time-series parameters and exogenous variables quantitatively as input conditions into the GTAP model related to uncertain drivers as follows.

4.2.1 Population and economic growth rate. Regarding population and economic growth rate, which are the first and second uncertain drivers listed in Table 1, this study uses data obtained from the SSP. In the BAU scenario, the population and real GDP growth rates of SSP2 (e.g. the average real GDP growth rate for Africa is $5.1 \%$ ), positioned as the intermediate situation among the five SSP scenarios, are adopted.

Moreover, scenario S1 assumes that the population of each African country is 10\% larger in 2040 ( 0.34 percentage points larger by year) than in the BAU scenario. This is derived from the share of African migrants with a higher level of education than secondary school (Organisation for Economic Co-operation and Development, 2015), who are expected to be workers in the context of TIs because the increase in employment opportunities is expected to decrease out-migration in Africa. In contrast, scenario S2 assumes that the population of each African country is $10 \%$ smaller in 2040 than in the BAU scenario, because of the decrease in employment opportunities is expected to increase out-migration in Africa. The left figure of Figure 2 shows the populations in Africa assumed in each scenario as well as those projected by the United Nations (2019). It indicates that the populations assumed in scenario S1 are almost identical to those in the low fertility variant scenario estimated by the United Nations. The labor force input in the model is assumed to increase or decrease at the same rate as the population.

The average annual GDP growth rate for each African country in scenarios S1 and S2 is assumed to be 1.5 percentage points larger and smaller, respectively, than that in the BAU scenario, with reference to African Development Bank (2011), based on the results of SPM 

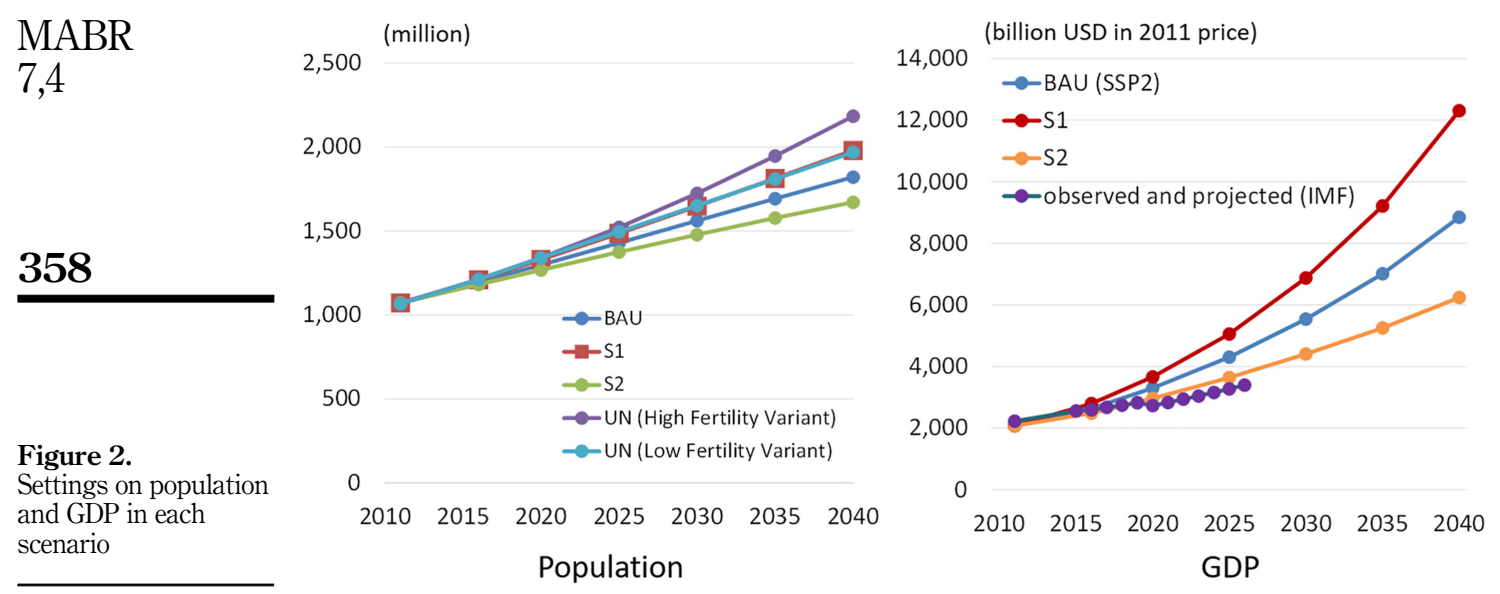

considering the increase in Africa's quality growth. The right figure of Figure 2 shows the real African GDPs assumed in each scenario as well as those observed and projected (until 2026) by IMF (2021). The real GDPs observed and projected by IMF (2021) are slightly smaller than those assumed in scenario S2.

4.2.2 Progress in free trade. Regarding bilateral and multilateral tariff reductions under FTAs or economic partnership agreements (EPAs), which is the third uncertain drivers in Table 1, information from the World Trade Organization (https://rtais.wto.org/) and the Japan External Trade Organization (https://www.jetro.go.jp/theme/wto-fta/ftalist.html) are used to set tariff parameters in the model's analysis. In Africa, in addition to the AfCFTA, the Southern African Development Community FTA came into effect in September 2000, the Common Market for Southeast Africa in October 2000, the Southern African Customs Union in July 2004 and the East African Community FTA in January 2005. The negotiation status of major FTAs and EPAs of the world as of March 2019 is summarized in Figure 3. In this study, tariffs are incrementally reduced and eliminated according to the negotiation status. Specifically, the tariffs are assumed to be fully eliminated in the period 2026-2030 by reducing $25 \%$ for each period from 2011 to 2016 respectively if they were in an effective stage as of 2016 (expressed as "1" in the figure) and fully eliminated in the period 2031-2035 by reducing 25\% for each period from 2017 to 2020 if they became an effective stage between 2017 and 2019 or were in a signature stage as of 2019 ("2") in all scenarios. Regarding the FTAs and EPAs in the negotiation stage, we separate them from those outside Africa ("3"), inside Africa except for the AfCFTA ("4") and in full operation by all African countries (i.e. the AfCFTA, " 5 "). In the BAU scenario, we assume the tariffs in the negotiation stage are all eliminated in the period 2036-2040 by reducing 25\% for each period from 2021 to 2025 except for the AfCFTA (i.e. "3" and "4" are realized, but " 5 " is not realized during the period), whereas all tariffs in the negotiation stage (" 3 ," " 4 ," and " 5 ") are eliminated in the period 2036-2040 by reducing $25 \%$ for each period from 2021 to 2025 in scenario S1 and only the tariffs between countries other than Africa in the negotiation stage (" 3 ") are eliminated in the period 20362040 by reducing $25 \%$ for each period from 2021 to 2025 in scenario S2 by assuming that all movements toward trade liberalization in Africa would stop thereafter.

4.2.3 Productivity growth in major sectors in Africa and global logistics sector. The variables related to productivity growth (including the advancement and acceptance of TIs) in the current major industrial sectors in Africa (i.e. agriculture and food, and natural 


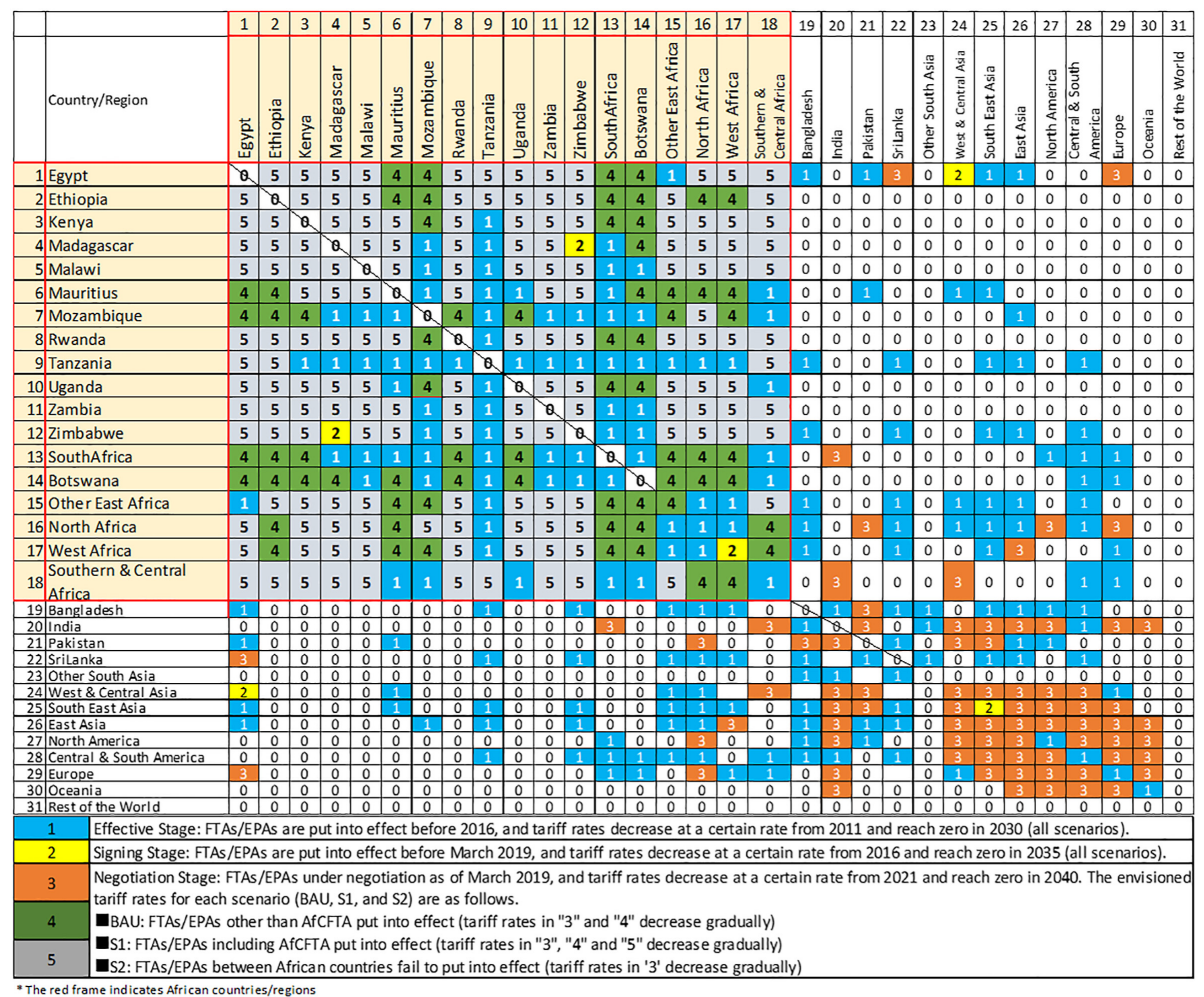

The growth of Africa's international trade

359

Figure 3.

Progress in free trade in the world and assumptions in this study

resources and energy) and the global logistics sector are also differently input into the GTAP model by scenario. In the BAU scenario, as summarized in Table 2, considering moderate growth in these sectors with moderate advancement and acceptance of TIs, these variables in African countries are set according to the average global growth rate from 2004 to 2011 as acquired from the GTAP Data Base 9. Note that, according to the GTAP Data Base 9, the annual productivity growth rates in these years in each African country were between -2.97 and $6.43 \%,-3.00$ and $11.5 \%$ and -1.92 and $9.67 \%$ in the agriculture and food sector, natural resources and energy sector and global logistics sector, respectively.

Notably, uncertainties in productivity growth by industrial development, including advancement and acceptance of TIs in the agriculture and food and global logistics sectors, are represented in the model as differences in the coefficient of technological advancement in each sector, whereas uncertainties in the natural resources and energy sector are represented as differences in natural resource endowment, considering the different roles of each sector in the production tree of the GTAP model. In scenario S1, EIPs and ECDPs are assumed to be largely realized through cooperation with various development agencies; thus, the average growth rates of these coefficients in Africa from 2004 to 2011, which are larger than the global average, are maintained until 2040 . In contrast, scenario S2 assumes that further productivity growth in these sectors will not be realized in Africa.

4.2.4 Other drivers. The other four drivers considered in the scenario building are not included as input conditions in the GTAP model in this study because of the reasons summarized in Table 3. 


\section{MABR 7,4}

\begin{tabular}{ll} 
Drivers & $\begin{array}{l}\text { Corresponding parameters in } \\
\text { GTAP model }\end{array}$ \\
\hline $\begin{array}{l}\text { Agriculture and food } \\
\text { (incl. agricultural TI) }\end{array}$ & $\begin{array}{l}\text { afeall (technological advancement) } \\
\text { in the agriculture and food sector }\end{array}$
\end{tabular}

\section{0}

\section{Table 2.}

Natural resources and

Summary of input conditions in agriculture and food, natural resources and energy and global logistics sectors

Growth rate per annum

BAU scenario Scenario S1 Scenario S2

$\begin{array}{lll}\text { Africa: } & \text { Africa: } & \text { Africa: } \\ 1.00 \% & 3.04 \% & 0.00 \% \\ \text { Non-Africa: } & \text { Non-Africa: } & \text { Non-Africa: } \\ 1.00 \% & 1.00 \% & 1.00 \% \\ \text { Africa: } & \text { Africa: } & \text { Africa: } \\ 1.20 \% & 2.40 \% & 0.00 \% \\ \text { Non-Africa: } & \text { Non-Africa: } & \text { Non-Africa: } \\ 1.20 \% & 1.20 \% & 1.20 \% \\ \text { Africa: } & \text { Africa: } & \text { Africa: } \\ 0.76 \% & 3.38 \% & 0.00 \% \\ \text { Non-Africa: } & \text { Non-Africa: } & \text { Non-Africa: } \\ 0.76 \% & 0.76 \% & 0.76 \%\end{array}$

Global logistics (incl. logistics TI) natres (natural resource

endowment)

ats and atd (technological advancement in global transport sector)

Drivers $\quad$ Reasons for not considering in the model

Realizing responsible supply chains

Stimulation of consumer confidence

Climate change

Table 3.

Drivers not considered
quantitatively as input conditions
War, conflict and terrorism

Multinational corporations are expected to spread the responsibility for human rights and the environment throughout their global supply chains, and thus create responsible supply chains. Although this is partly considered in terms of technological advancement (ats and $a t d$ ) in the global transport sector, this study does not implicitly consider this driver as an input condition because it is difficult to express it quantitatively

In the GTAP model, consumption activities are assumed to be carried out without excess or deficiency following the economic growth of each country and region. Therefore, it is not considered as an input condition

In all the scenarios of this study, moderate climate change risk is assumed in the long-term predictions. In the SSP2 that is adopted to the BAU scenario of this study, moderate climate change risk is considered. Moreover, the settings in African countries in scenarios S1 and S2 are generally within the values assumed in other SSP scenarios. Therefore, this study does not consider this driver as an additional input condition

Although the risks of war, conflict and terrorism exist, it is difficult to estimate its probability of occurrence, scale and impact on international trade. Therefore, its impact is not considered in this study

\section{Estimation results and discussions}

\subsection{Trade values in Africa}

Figure 4 presents the forecasted compound average growth rates (CAGRs) of total imports and exports by country for all industrial sectors from 2011 to 2040 . Total international trade (in 2011 prices) is projected to grow from USD 19,130 billion in 2011 to 47,482 billion in 2040 under the BAU scenario (a 148\% increase over 2011 and 3.2\% for CAGR), by USD 48,914 billion under scenario S1 (a 156\% increase over 2011 and 3.3\% for CAGR) and by USD 46,812 billion under scenario S2 (a 145\% increase over 2011 and 3.1\% for CAGR). In other words, the success or failure of EIPs and ECDPs, including the AfCFTA and the advancement and acceptance of TIs in major sectors, would result in a global difference of USD 2,102 billion, which is the difference between scenarios S1 and S2 and equivalent to 11 percentage points, that is, the variability due to the uncertainties in Africa. 


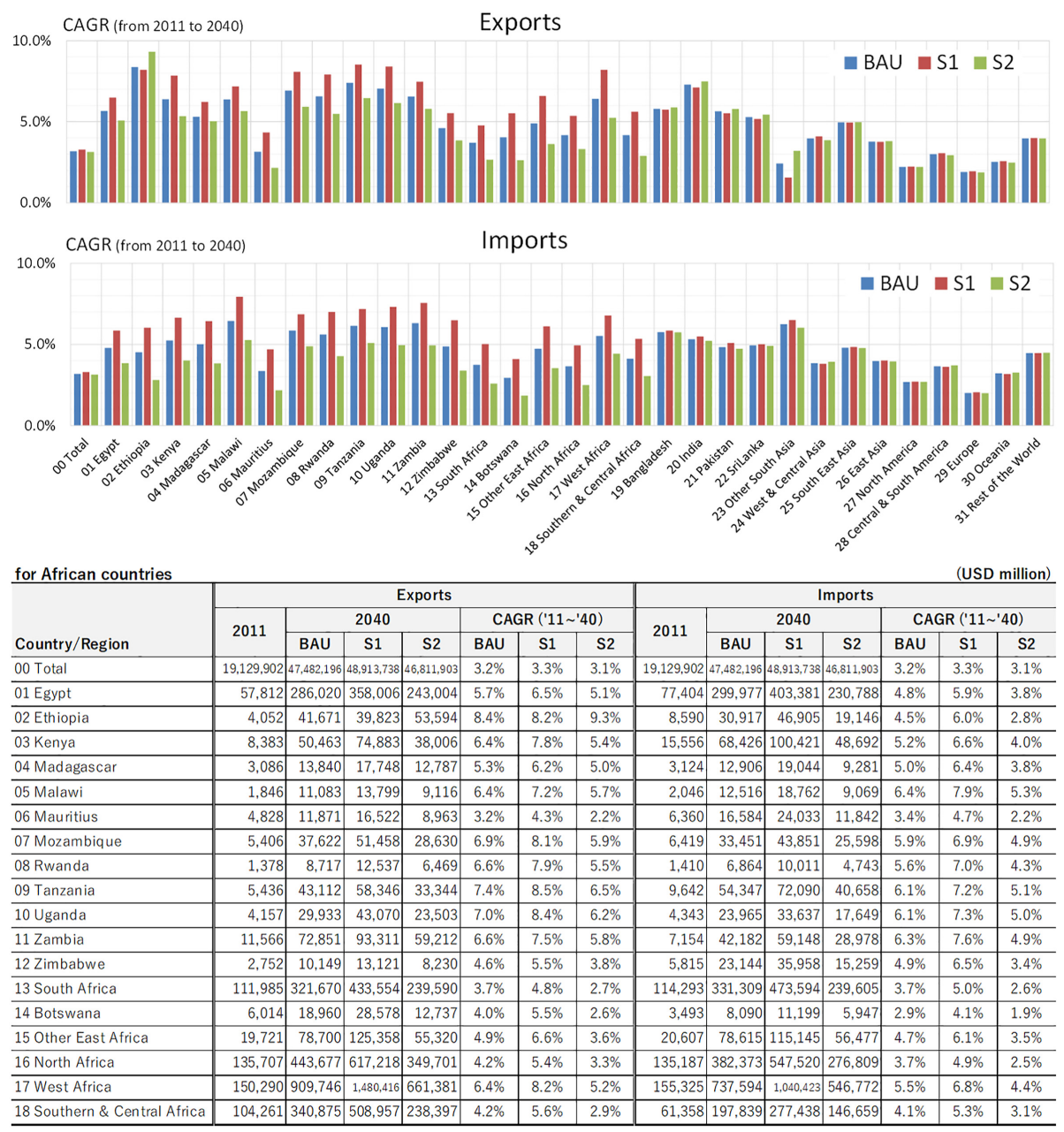

The growth of Africa's international trade

361

Figure 4.

Forecasted average growth rate of total trade values (2011-2040)

Figure 5 indicates the growth process of the trade amounts until 2040 in each scenario (in 2011 prices) in the African continent and specifically in Kenya and Ethiopia as representative cases. It also shows the observed trade amounts (in 2011 prices) until 2019, which are calculated from the observed growth rates of trade volume acquired from the website of the World Trade Organization (https:/timeseries.wto.org/). In particular, the observed import amount in Ethiopia was significantly larger than those in any other scenarios. This difference was mainly due to the significant increase in the import of machinery and transport equipment from 2012 to 2015 for the railway development. In other words, infrastructure investment during this period in Ethiopia was beyond expectation. However, we conclude the trends of the entire African trade were generally represented by the model.

As indicated in Figure 5, Africa's total exports (in 2011 prices) grow from USD 639 billion in 2011 to 2,731 billion in 2040 (a 327\% increase over 2011) under the BAU scenario, 3,987 billion (a $524 \%$ increase) in scenario S1 and 2,082 billion (a $226 \%$ increase) in scenario S2. The difference between scenarios S1 and S2, which is produced due to the uncertainties in Africa, 

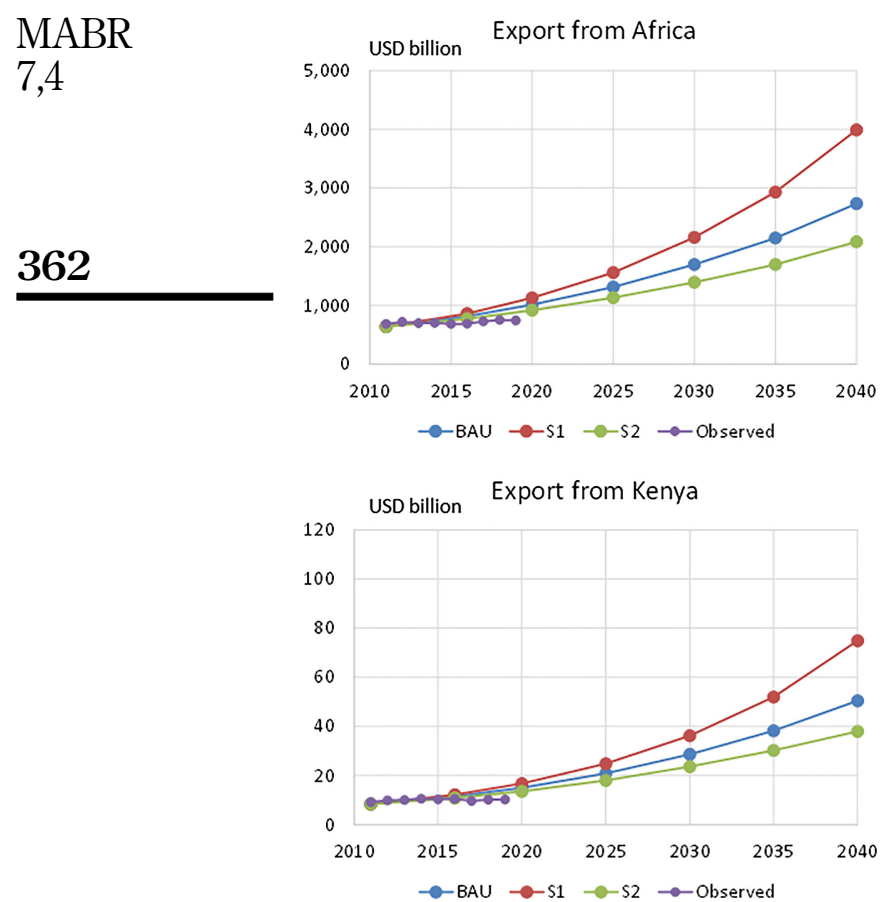

USD billion Export from Ethiopia

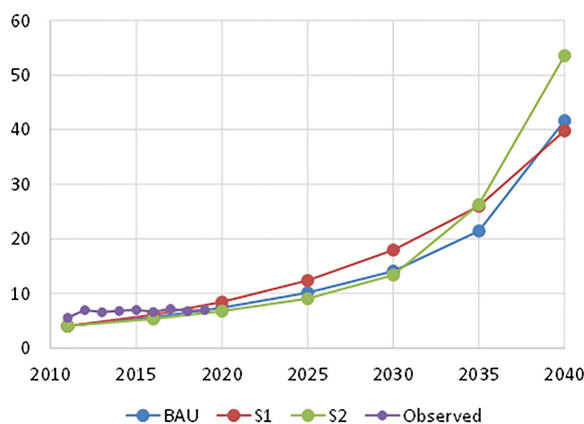

Figure 5.

Forecasted

international trade growth for Africa, and Kenya and Ethiopia
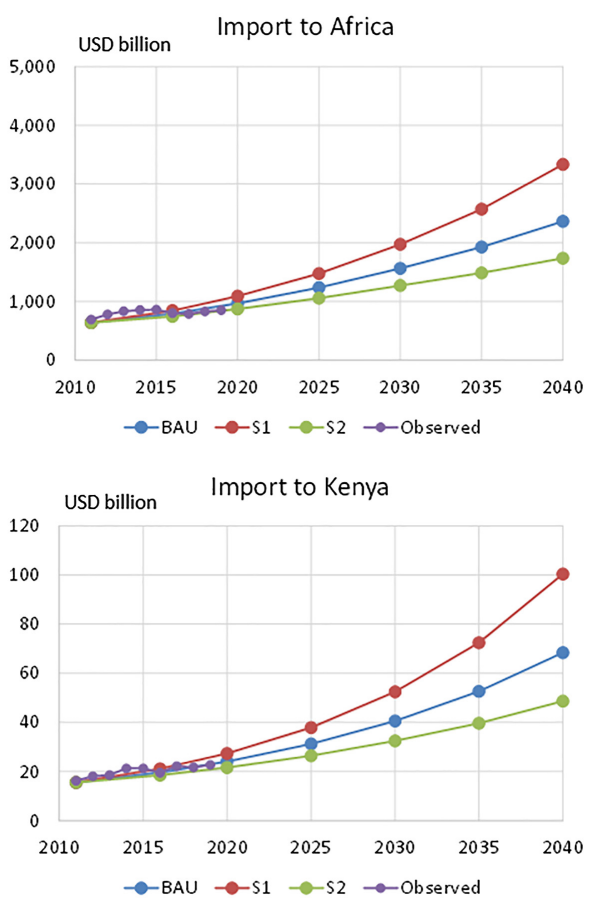

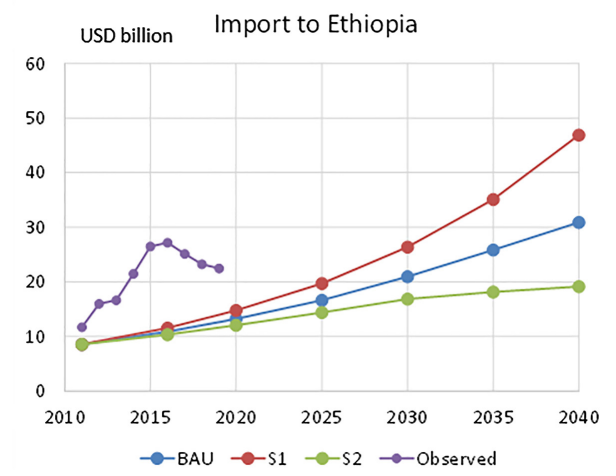

is USD 1,905 billion or 298 percentage points. Africa's total imports (in 2011 prices) grow from USD 638 billion in 2011 to 2,361 billion in 2040 (a 270\% increase over 2011) under the BAU scenario, 3,333 billion (422\% increase over 2011) in scenario S1 and 1,734 billion $(172 \%$ increase over 2011) in scenario S2. The difference between scenarios S1 and S2 is USD 1,599 billion, or 250 percentage points. In summary, the success of EIPs and ECDPs will significantly increase the value of African imports and exports. Specifically, if we focus on the trade in the agriculture and food sector, the estimated CAGR from 2011 to 2040 in scenario S1 is $8.8 \%$, which is larger than for GDP $(6.3 \%)$, as envisioned in the scenario. However, the CAGR in other sectors $(6.2 \%)$ is similar to that of GDP, which is different from the scenario prediction, because industrial development in other sectors is not implicitly considered in 
this study. Meanwhile, in scenario S2, the CAGR in sectors other than the agriculture and food is $3.8 \%$, which is similar to that for GDP $(3.9 \%)$, as envisioned in the scenario; however, the CAGR in the agriculture and food sector $(3.0 \%)$ is slightly smaller than that of GDP, which is different from the scenario prediction. These results should be reviewed after considering industrial development in sectors other than the agriculture and food. In terms of the disparity in Africa, which was also predicted in the scenario, the standard deviation of the CAGR of trade in African countries from 2011 to 2040 is the smallest in scenario S1 and the largest in scenario S2 (BAU: 1.11, S1: 1.07 and S2: 1.24 percentage points), resulting in a reduction in the disparity due to the success of EIPs and ECDPs as envisioned in the scenario.

Regarding the trade in Kenya, as indicated in Figure 5, scenario S1 has the highest import and export value, whereas scenario S2 has the lowest value. However, in Ethiopia, the import and export growth rates in scenario S1 are lower than in scenario S2 for many industrial sectors, such as mining and consumer goods. As a landlocked country, Ethiopia is unique in that its international trade relies heavily on the neighboring country, Djibouti, for a gateway seaport; therefore, its share of intra-regional trade is relatively low, similar to other geographically isolated countries in Africa, such as Egypt, Madagascar and Mauritius, compared with other African countries. For Ethiopia, the benefits of EIPs and ECDPs aiming to promote African international trade, including intra-regional trade, are very limited. This suggests the possible importance of ECDPs with neighboring countries other than Djibouti, such as Kenya and Sudan, to enjoy the benefits of EIPs in Africa.

Similarly, several negative effects are observed in some countries, where the CAGR of trade in scenario S1 is lower than in scenario S2. They can be interpreted as the result of changes in the relative prices of goods due to tariff reductions and eliminations associated with the implementation of EIPs and the progress of inter-regional substitution due to the principle of competition. Nouve and Wodon (2008) compared the reduction of import tariffs on rice with an increase in productivity and found that, especially for developing countries with a large low-income population such as Mali, the increase in productivity provides greater economic benefits than a reduction in import tariffs. The World Bank (2020) also indicated that if the AfCFTA were to be implemented with only tariff elimination and without a sufficient removal of non-tariff barriers and trade promotion policies, the future increase in trade would remain low for some industrial sectors. In this study, although TIs in the major sectors through EIPs and ECDPs are examined as scenario analyses in addition to tariff reduction and elimination, some results suggest that the negative effects of tariff reductions and elimination may exceed the positive effects of those factors. However, even in Ethiopia, the trade value in scenario S1 exceeds that of scenario S2 in several industrial sectors, including agriculture and food and industrial materials, suggesting that some factors considered as uncertainties in Africa in the scenarios may have some positive effects even in countries where tariff reductions and removals have adverse effects.

\subsection{Trade values between Africa and other regions in the world}

Figure 6 shows the changes in import and export trade between Africa and other regions in the world by scenario. Exports from Africa to the rest of the world are predicted as USD 1,934 billion (in 2011 prices) in 2040 under the BAU scenario, compared with USD 3,200 billion in scenario S1 and USD 1,800 billion in scenario S2, with a difference of 1,400 billion depending on the success of EIPs and ECDPs in Africa. In scenario S1, the growth rates of exports from Africa to South and Southeast Asia are higher than exports to North America and Europe, which are currently Africa's major trading partners. Similarly, imports are predicted to increase to 2,600 billion USD (in 2011 prices) in 2040 in scenario S1 and USD 1,400 billion in scenario S2, with a difference of 1,200 billion. As is the case of exports, imports from East and South Asia are also expected to increase.
The growth of Africa's international trade

363 


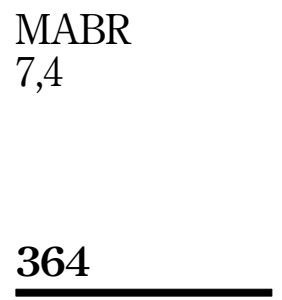

Figure 6.

Forecasted future exports and imports between Africa and each region of the world

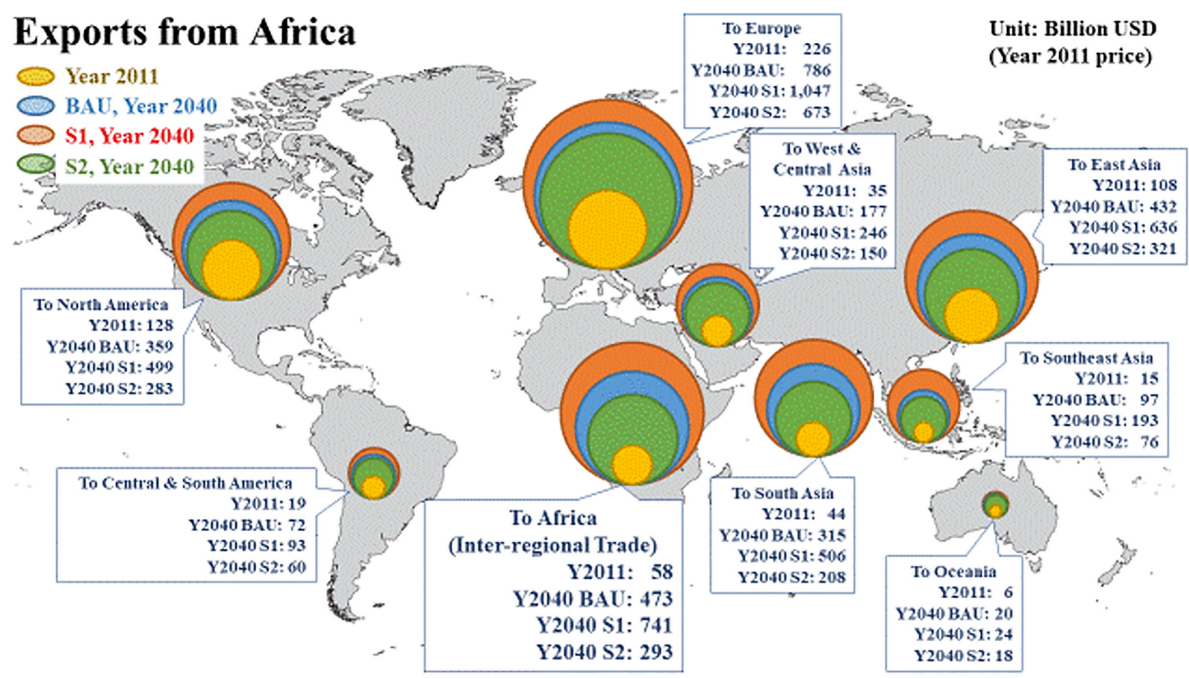

\section{Imports to Africa}

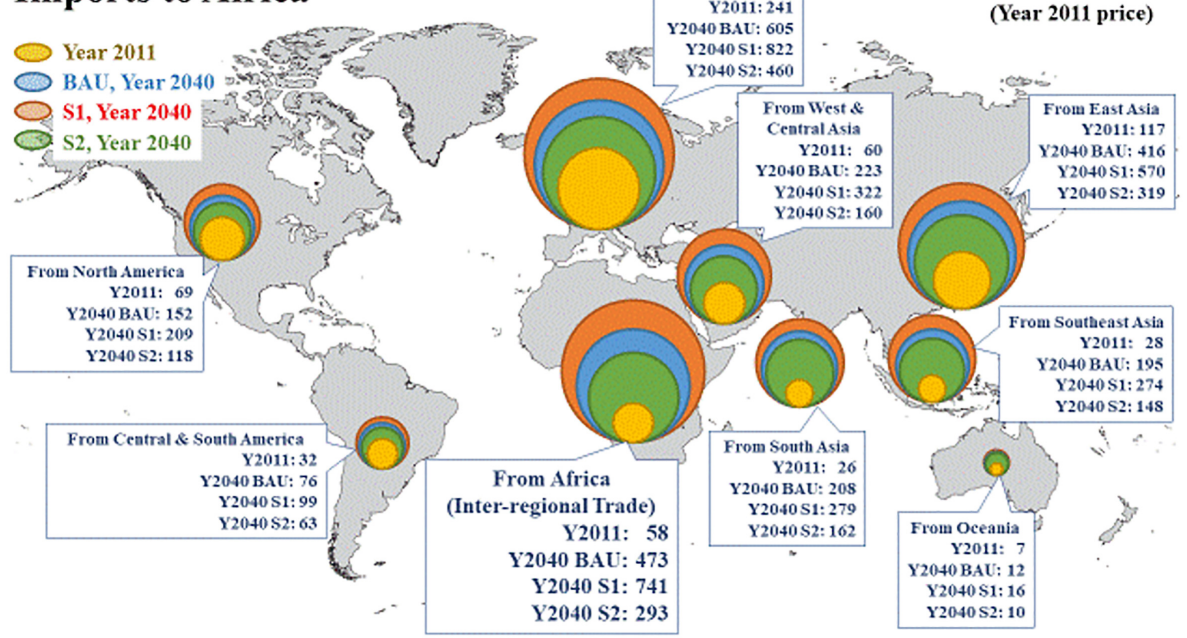

The African region is predicted to increase the largest in trade with Europe in 2040-currently the major trading partner for African countries-followed by African intra-regional trade. Whereas the World Bank (2020) estimated that the AfCFTA may cause African intra-regional trade to increase by $81 \%$ from 2020 to 2035 , this study estimates an increase in intra-regional trade of $289 \%$ over the same period (from USD 126 billion in 2020 to 490 billion in 2035). This considerable difference can be attributed to the fact that, whereas the World Bank (2020) quantified the impact of AfCFTA by itself, this study considers various factors such as EIPs and ECDPs in an integrated way, not only the AfCFTA but also other FTAs and EPAs and industrial development through TIs in the major and global logistics sectors in Africa.

To summarize, EIPs and ECDPs are expected to have economic effects by increasing African intra-regional trade and expanding trade with Asia. Therefore, when planning 
logistics infrastructure development, it is important to focus more on African intra-regional trade and trade with South and Southeast Asia.

\subsection{Trade values by industry}

Figure 7 presents the predicted results of CAGRs by industrial sector in Africa. The CAGR of agricultural exports for each African country in scenario S1 is higher than in scenario S2, and the average difference is 9.5 percentage points, which is the largest compared to other sectors; the consumer goods sector is the second largest, with a difference of 2.0 percentage points between the two scenarios.

Regarding imports, scenario S1 tends to show the largest increase in many sectors, and this trend is more pronounced than for exports. From the perspective of improving food selfsufficiency, which is a long-standing issue in Africa, imports of the agriculture and food sector estimated in scenario S1 are lower than those in scenario S2. However, when focusing on import value for each county - not shown in the figure due to space limitations - in 9 countries/regions, half of the 18 African countries/regions analyzed, the increasing rates of imports in the agriculture and food sector in scenario S1 are higher than in scenario S2. This suggests that the success of EIPs and ECDPs in scenario S1 could lead to higher imports of cheap food; this could suppress the growth of the domestic agriculture and food sector and worsen food self-sufficiency. Meanwhile, the share of exports in the total trade in the agriculture and food sector in African countries is predicted to be, on average, 41.5 percentage points higher in scenario S1 than in scenario S2 as of 2040. Moreover, in some landlocked countries such as Rwanda, Uganda and Botswana, their agricultural imports in scenario S1

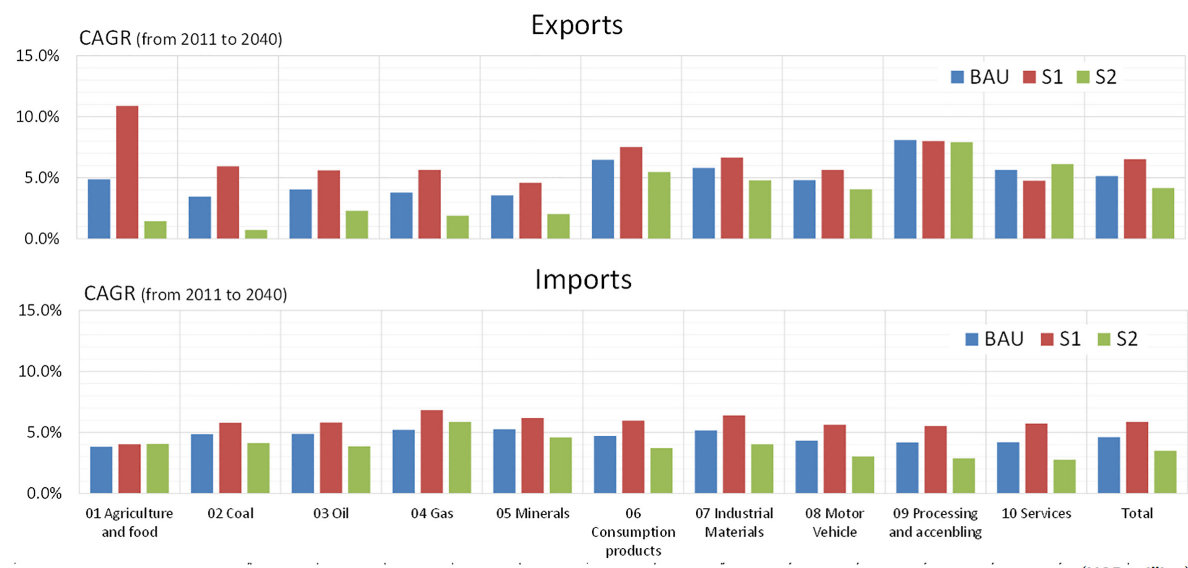

\begin{tabular}{|c|c|c|c|c|c|c|c|c|c|c|c|c|c|c|}
\hline \multirow[b]{2}{*}{ Industrial Sector } & \multirow{2}{*}{2011} & \multicolumn{3}{|c|}{2040} & \multicolumn{3}{|c|}{ CAGR ('11 '40) } & \multirow{2}{*}{2011} & \multicolumn{3}{|c|}{2040} & \multicolumn{3}{|c|}{ CAGR ('11 '40) } \\
\hline & & $\mathrm{BAU}$ & S1 & S2 & BAU & S1 & $\mathrm{S} 2$ & & $\mathrm{BAU}$ & S1 & S2 & BAU & S1 & S2 \\
\hline 01 Agriculture and food & 34,283 & 135,932 & 687,379 & 51,879 & $4.9 \%$ & $10.9 \%$ & $1.4 \%$ & 33,774 & 100,604 & 106,563 & 107,356 & $3.8 \%$ & $4.0 \%$ & $4.1 \%$ \\
\hline 02 Coal & 6,676 & 17,936 & 35,582 & 8,238 & $3.5 \%$ & $5.9 \%$ & $0.7 \%$ & 1,274 & 5,064 & 6,541 & 4,114 & $4.9 \%$ & $5.8 \%$ & $4.1 \%$ \\
\hline 03 Oil & 237,143 & 748,791 & $1,155,428$ & 457,391 & $4.0 \%$ & $5.6 \%$ & $2.3 \%$ & 24,916 & 99,320 & 128,218 & 74,985 & $4.9 \%$ & $5.8 \%$ & $3.9 \%$ \\
\hline 04 Gas & 35,001 & 102,948 & 171,663 & 60,238 & $3.8 \%$ & $5.6 \%$ & $1.9 \%$ & 1,306 & 5,723 & 8,893 & 6,826 & $5.2 \%$ & $6.8 \%$ & $5.9 \%$ \\
\hline 05 Minerals & 33,988 & 93,434 & 124,561 & 60,734 & $3.5 \%$ & $4.6 \%$ & $2.0 \%$ & 6,730 & 29,801 & 38,353 & 24,826 & $5.3 \%$ & $6.2 \%$ & $4.6 \%$ \\
\hline 06 Consumption products & 50,153 & 308,606 & 411,707 & 235,138 & $6.5 \%$ & $7.5 \%$ & $5.5 \%$ & 106,557 & 405,633 & 572,040 & 306,384 & $4.7 \%$ & $6.0 \%$ & $3.7 \%$ \\
\hline 07 Industrial Materials & 122,195 & 628,284 & 792,748 & 474,513 & $5.8 \%$ & $6.7 \%$ & $4.8 \%$ & 181,867 & 781,451 & $1,098,723$ & 572,417 & $5.2 \%$ & $6.4 \%$ & $4.0 \%$ \\
\hline 08 Motor Vehicle & 9,784 & 38,084 & 47,962 & 31,047 & $4.8 \%$ & $5.6 \%$ & $4.1 \%$ & 40,629 & 139,283 & 199,033 & 96,503 & $4.3 \%$ & $5.6 \%$ & $3.0 \%$ \\
\hline 09 Processing and accenblin & 25,542 & 243,743 & 237,898 & 232,354 & $8.1 \%$ & $8.0 \%$ & $7.9 \%$ & 137,222 & 451,590 & 652,006 & 311,832 & $4.2 \%$ & $5.5 \%$ & $2.9 \%$ \\
\hline 10 Services & 83,914 & 413,202 & 321,778 & 470,455 & $5.7 \%$ & $4.7 \%$ & $6.1 \%$ & 103,850 & 342,630 & 522,193 & 228,730 & $4.2 \%$ & $5.7 \%$ & $2.8 \%$ \\
\hline Total & 638,680 & $2,730,960$ & $3,986,706$ & $2,081,987$ & $5.1 \%$ & $6.5 \%$ & $4.2 \%$ & 638,125 & $2,361,100$ & $3,332,563$ & $1,733,973$ & $4.6 \%$ & $5.9 \%$ & $3.5 \%$ \\
\hline
\end{tabular}

Figure 7.

Forecasted average growth rate by industrial sector in Africa 
MABR

7,4

366

are $10 \%-20 \%$ lower than in scenario S2. These results can be interpreted as a significant increase in domestic production of agricultural goods in Africa, especially in landlocked countries, because of industrial development and productivity growth in the agricultural and logistics sectors, including the advancement and acceptance of TIs in scenario S1.

Regarding countries and regions outside Africa, which are not included in any of the figures due to space limitations, the growth in import and export trade value in each sector is not uniform and differs among the scenarios despite the common parameters set for all the scenarios. This result indicates that because of the expansion of globalization, the success or failure of EIPs and ECDPs in Africa could have a positive or negative impact not only within Africa but also in other parts of the world. Particularly for the agriculture and food sector as well as consumption products and industrial materials sectors in Bangladesh, India and Pakistan in the South Asian region, scenario S1 presents the highest growth in imports and the lowest growth in exports among the three scenarios. This result suggests that if EIPs and ECDPs strengthen the international competitiveness of African countries, these South Asian countries, which are geographically close to African countries and have close economic ties with Africa, are predicted to be more exposed to competition from African countries.

\section{Conclusions}

This study developed three future scenarios by applying SPM to consider the uncertainties in African economies. Based on these scenarios, African countries' future trade was predicted using the GTAP model and considering uncertainties in EIPs and ECDPs, such as the progress of many FTAs (including the AfCFTA) and advancement and acceptance of TIs, as input conditions in the prediction. The findings of this study are summarized below.

Under scenario S1, in which EIPs and ECDPs succeed, Africa's trade would increase significantly, resulting in a difference of about USD 1,900 billion in exports and about USD 1,600 billion in imports in 2040, compared with scenario S2, in which they fail. These differences can be attributed to socioeconomic uncertainties inherent in African countries, including the achievement of free trade and productivity growth in major industries with the advancement and acceptance of TIs. Moreover, as predicted, the success of EIPs and ECDPs in scenario S1 resulted in a reduction in the disparity between African countries and in the growth in trade, especially in the agriculture and food sector.

However, the significance of the effects varied between countries and industrial sectors, and in some cases, the rate of increase in trade in scenario $\mathrm{S} 2$ was higher than that in scenario S1. Although the results acquired in this study corresponded to other studies, including those of the World Bank (2020), greater differences were observed in the agriculture and food and consumer goods sectors in landlocked countries such as Ethiopia, Rwanda, Uganda and Botswana. This could be interpreted as a result of considering the uncertainties in Africa regarding EIPs and ECDPs; in other words, the impacts of EIPs and ECDPs on trade could be positive or negative, depending on the industrial and geographical characteristics of the country. Therefore, when implementing these policies, especially in countries such as Ethiopia, where some industries will be negatively affected, it is important to consider in advance: (1) which tariffs will be reduced or eliminated and their timing and (2) how to cooperate with neighboring governments, international donors and other stakeholders related to the ECDP, while taking into account the characteristics of the country.

Moreover, this study found that the success or failure of EIPs and ECDPs in Africa could have a significant impact on countries outside Africa. The value of the trade between Africa and the rest of the world was predicted to increase drastically in scenario S1, particularly trade with countries in the Indo-Pacific region. In contrast, scenario S1 predicted a slowdown in exports from South Asia to the rest of the world. This suggests that with the success of 
EIPs and ECDPs, African export goods might become more competitive in the world market, thus undermining competitors in South Asia.

African intra-regional trade would also increase significantly in scenario S1, from USD 58 billion in 2011 to 741 billion in 2040, indicating that the success of EIPs and ECDPs would greatly encourage intra-regional trade. These results are qualitatively consistent with predictions by the World Bank (2020). However, they had led to different quantitative results because the World Bank (2020) analyzed the individual effects of the AfCFTA, whereas this study considered the integrated effects of EIPs and ECDPs in addition to the AfCFTA.

As mentioned above, the results of this study underscored the importance of EIPs and ECDPs in Africa. However, some issues need to be addressed in the future. First, the GTAP model used in this study considers a variety of variables, but the model needs to be extended for a more detailed analysis. For example, because the input-output structure of the base year was taken as a given in the GTAP model, it is difficult to express changes that significantly alter the industrial structure. This is particularly important when discussing how the COVID-19 pandemic would change the world's industrial structure and supply chain network including decarbonisation. Another issue is that in the GTAP model, an improvement in logistics infrastructure is simply considered as the productivity growth of the global logistics sector, but the impact of ECDPs would differ depending on each region, transport route or link in the global logistics network. Regarding this issue, the global logistics intermodal network simulation model developed by Shibasaki et al. (2020) allows for the analysis of freight flows by considering the constraints in capacities of each logistics infrastructure related to international trade, including maritime container shipping services, ports, roads, railways, inland waterway transports and cross-border facilities. In the future, when formulating a more specific strategy for the development of logistics infrastructure in Africa, a combined analysis that takes advantage of the characteristics of both economic models, such as the GTAP model and logistics models, such as the global logistics intermodal network simulation model, is necessary.

\section{References}

African Development Bank (2011), Africa in 50 Years' Time, African Development Bank, Tunis, available at: http://globaltrends.thedialogue.org/wp-content/uploads/2014/11/AFRICA-2060.pdf (accessed 08 July 2021).

African Development Bank (2016), African Economic Outlook 2016, African Development Bank, Abidjan, available at: https://www.afdb.org/en/documents/document/african-economic-outlookaeo-2016-88787 (accessed 08 July 2021).

African Development Bank (2017), African Economic Outlook 2017, African Development Bank, Abidjan, available at: https://www.afdb.org/en/documents/document/african-economic-outlookaeo-2017-95818 (accessed 08 July 2021).

African Development Bank (2018), African Economic Outlook 2018, African Development Bank, Abidjan, available at: https://www.afdb.org/en/documents/document/african-economic-outlookaoe-2018-99877 (accessed 08 July 2021).

African Development Bank (2020), African Economic Outlook 2020, African Development Bank, Abidjan, available at: https://www.afdb.org/en/documents/african-economic-outlook-2020 (accessed 08 July 2021).

African Export-Import Bank (2018), African Trade Report 2018, The African Export-Import Bank, Cairo, available at: https://www.tralac.org/documents/news/2042-african-trade-report-2018afreximbank/file.html (accessed 13 July 2021).

African Union (2020), "Decision on the start of trading under the African continental free trade Area (AfCFTA)", No: Ext/Assembly/Dec.1(XIII), December 05, 2020, available at: https://afcfta.au.int/ en/documents/2020-12-05/decision-start-trading-under-afcfta (accessed 10 December 2020).
The growth of Africa's international trade 
MABR 7,4

Aguiar, A., Narayanan, B. and McDougall, R. (2016), "An overview of the GTAP 9 data base”, Journal of Global Economic Analysis, Vol. 1 No. 1, pp. 181-208.

Anderson, K. and Strutt, A. (2014), "Emerging economies, productivity growth and trade with resource-rich economies by 2030", Australian Journal of Agricultural and Resource Economics, Vol. 58, pp. 590-606.

Anderson, K. and Strutt, A. (2016), "Impacts of emerging Asia on African and Latin American trade: projections to 2030", The World Economy, Vol. 39 No. 2, pp. 172-194.

Brian, C.O., Kriegler, E., Ebi, K.L., Kemp-Benedict, E., Riahi, K., Rothman, D.S., van Ruijven, B.J., van Vuuren, D.P., Birkmann, J., Kok, K., Levy, M. and Solecki, W. (2015), "The roads ahead: Narratives for shared socioeconomic pathways describing world futures in the 21st century", Global Environmental Change, Vol. 42, pp. 169-180.

Burfisher, M.E. (2011), Introduction to Computable General Equilibrium Models, Cambridge University Press, Cambridge.

Chakraborty, A. and McMillan, A. (2015), "Scenario planning for urban planners: toward a practitioner's guide", Journal of the American Planning Association, Vol. 81 No. 1, pp. 18-29.

Chikhuri, K. (2013), "Impact of alternative agricultural trade liberalization strategies on food security in the Sub-Saharan Africa region”, International Journal of Social Economics, Vol. 40 No. 3, pp. 188-206.

Dellink, R., Mensbrugghe, D.V.D. and Saveyn, B. (2020), "Shaping baseline scenarios of economic activity with CGE models: introduction to the special issue", Journal of Global Economic Analysis, Vol. 5 No. 1, pp. 1-27.

Erdogan, B., Abbott, C., Aouad, G. and Kazi, S. (2009), "Construction IT in 2030: a scenario planning approach", Journal of Information Technology in Construction, Vol. 14, pp. 539-555.

International Monetary Fund (2021), "World economic outlook”, available at: https://www.imf.org/en/ Publications/WEO/weo-database/2021/April (accessed 04 November 2021).

Kawai, H. (2012), "Mining future information on web”, DEIM 2012 Tutorial, available at: https://dbevent.jpn.org/deim2012/data/uploads/t2.pdf (accessed 05 November 2020).

Kosuge, N., Shibasaki, R., Sanui, K. and Okubo, K. (2021), "Impact of Cambodian international logistics policies on container cargo flow in comprehensive intermodal transport network", International Journal of Logistics Research and Applications (in press).

McDougall, R.A., Walmsley, T., Golub, A., Ianchovichina, E. and Itakura, K. (2012), "An overview of the Dynamic GTAP Data Base: the data base construction and aggregation programs", in Ianchovichina, E. and Walmsley, R. (Eds), Dynamic Modeling and Applications for Global Economic Analysis, Cambridge University Press, pp. 120-135.

Ministry of Economy, Trade and Industry of Japan (2020), "White paper on international economy and trade 2020", available at: https://www.meti.go.jp/english/report/data/wp2020/wp2020.html (accessed 05 November 2020).

Ministry of Foreign Affairs of Japan (2019), "Yokohama declaration”, Yokohama, August 30, 2020, available at: https://www.mofa.go.jp/region/africa/ticad/ticad7/pdf/yokohama_declaration_en. pdf (accessed 05 November 2020).

Ministry of Foreign Affairs of Japan (2020), "White paper on development cooperation 2019", available at: https://www.mofa.go.jp/mofaj/gaiko/oda/files/100161421.pdf (accessed 22 March 2021).

Morris, M. (2014), "The industrialisation challenge for Africa: towards a commodities based industrialisation path", Journal of African Trade, Vol. 1, pp. 25-36.

Nouve, K. and Wodon, Q. (2008), "Impact of rising prices and policy responses in mali: simulations with a dynamic CGE model", World Bank Policy Research Working Paper 4739, The World Bank, Washington, DC. 
Nugroho, A., WidyastutikIrawan, T. and Amaliah (2021), "Does the US-China trade war increase poverty in a developing country? A dynamic general equilibrium analysis for Indonesia", Economic Analysis and Policy, Vol. 71, pp. 279-290.

Organisation for Economic Co-operation and Development (2015), "Database on immigrants in OECD and non-OECD countries", available at: https://www.oecd.org/els/mig/dioc.htm (accessed 5 November 2020).

Ouedraogo, N.S. (2017), "Africa energy future: alternative scenarios and their implications for sustainable development strategies”, Energy Policy, No. 106, pp. 457-471.

O’Brien, P. (2000), Scenario Planning: A Strategic Tool, Bureau of Rural Sciences, Canberra.

Pasara, M.T. and Dunga, S.H. (2020), "Who wins and who loses under the AFCFTA? A simulation analysis across ECOWAS countries", International Journal of Economics and Finance Studies, Vol. 12 No. 2, pp. 487-504.

Schwartz, P. (1996), The Art of the Long View: Planning for the Future in an Uncertain World, Currency, New York.

Servén, L. (1997), Uncertainty, Instability, and Irreversible Investment: Theory, Evidence, and Lessons for Africa, Policy Research Working Paper 1722, The World Bank, Washington, DC.

Shibasaki, R. and Watanabe, T. (2012), "Future forecast of trade amount and international cargo flow in the APEC region: an application of trade-logistics forecasting model", Asian Transport Studies, Vol. 2 No. 2, pp. 194-208.

Shibasaki, R., Kato, H. and Ducruet, C. (Eds) (2020), Global Logistics Network Modelling and Policy: Quantification and Analysis for International Freight, Elsevier, Amsterdam.

Soete, L. (1985), "International diffusion of technology, industrial development and technological leapfrogging", World Development, Vol. 13 No. 3, pp. 409-422.

The Institute of Energy Economics, Japan (2017), "IEEJ Outlook 2018", The Institute of Energy Economics, Japan.

United Nations (2019), “World population prospects 2019”, available at: https://population.un.org/wpp/ (accessed 04 November 2021).

United Nations Conference on Trade and Development (2019), Economic and Development in Africa Report 2019: Made in Africa - Rules of Origin for Enhanced Intra-African Trade, United Nations Publications, New York.

World Bank (2020), The African Continental Free Trade Area: Economic and Distributional Effects, The World Bank, Washington, DC, available at: https://openknowledge.worldbank.org/handle/ 10986/34139 (accessed 08 July 2021).

Zegras, C., Sussmand, J. and Cooklin, C. (2004), "Scenario planning for strategic regional transportation planning", Journal of Urban Planning and Development, Vol. 130 No. 1, pp. 3-13.

\section{Corresponding author}

Ryuichi Shibasaki can be contacted at: shibasaki@tmi.t.u-tokyo.ac.jp
The growth of Africa's international trade 